\title{
EFEKTIVITAS SIM SIAGA \\ TERHADAP PENGELOLAAN MANAJEMEN GURU PAIS DI KANTOR KEMENTERIAN AGAMA KABUPATEN BANGKALAN
}

\author{
Holifah Kurniyah, Imam Tirmidzi A, Nur Hasanah \\ UIN Sunan Ampel, Surabaya - Indonesia | holifahkurniyah12@gmail.com
}

\begin{abstract}
Abstrak: Penelitian ini bertujuan untuk mengetahui dan mendeskripsikan tentang efektivitas SIM SIAGA terhadap pengelolaan manajemen guru PAIS di kantor kementerian agama kabupaten Bangkalan. Metode penelitian yang digunakan adalah penelitian kualitatif pendekatan deskriptif. Teknik pengumpulan data dilakukandenganobservasilapangan dan wawancara yang dilakukan pada tanggal tugas yang telah ditetapkan oleh kampus terkait. Hasil penelitian menunjukkan bahwa efektivitas SIM SIAGA terhadap pengelolaan manajemen guru PAIS di kantor kementerian agama kabupaten Bangkalan dinilai sangat efektif untuk digunakan dibandingkan aplikasi Emis. dimana beberapa fitur-fitur yang sangat mendukung didalamnya, dan sama sekali tidak menemukan kendala apapun. meskipun ada sebagian fitur yang masih tidak dapat berjalan secara efektif dikarenakan aplikasi tersebut masih terbilang sangat baru yang membutuhkan inovasi-inovasi dalam pengembangannya.
\end{abstract}

Keywords: efektivitas SIM SIAGA, manajemen guru PAIS

\section{Pemdahuluan}

Sistem informasi manajemen (SIM) merupakan kebutuhan yang diperlukan suatu organisasi untuk mencapai efektifitas dan efisensi kerja khususnya dalam era perkembangan teknologi modern saat ini. Perkembangan teknologi mendorong adanya pengembangan pengelolaan administrasi organisasi dari sistem tradisional menjadi sistem berbasis teknologi informasi. Salah satu manfaat dari sistem informasi manajemen dalam organisasi pendidikan adalah sebagai sarana pengambilan keputusan untuk peningkatan layanan pendidikan. Karena administrasi pada hakikatnya adalah 
pengambilan keputusan. Karena setiap kegiatan di dalam organisasi pasti terdapat permasalahan yang harus diselesaikan, dan yang perlu untuk di evaluasi baik dengan cara demokratis maupun menggunakan otoritas pimpinan. Keputusan yang baik memerlukan pemahaman tentang masalah dan pengetahuan tentang alternatif pemecahannya. Ketepatan dan keakuratan informasi yang baik akan mempengaruhi pengambilan keputusan yang baik pula. Sistem Informasi Manajemen (SIM) merupakan jaringan informasi yang dibutuhkan pimpinan dalam menjalankan tugasnya (untuk kepentingan organisasi), terutama dalam mengambil keputusan dalam mencapai tujuan organisasinya.

Sedangkan efektivitas secara bahasa Inggris yaitu effective yang memiliki arti tercapai atau berhasil atas sesuatu yang dilakukan. Berdasarkan kamus ilmiah yang dimaksud dengan Efektivitas merupakan cara ketepatan waktu yang digunakan atau sesuatu yang dihasilkan yang dapat menunjang tujuan yang ditetapkan. Efektivitas adalah kesatuan dari beberapa unsure pokok yang digunakan sebagai bahan dalam meraih sasaran dan tujuan yang ingin dicapai dalam suatu organisasi baik berupa kegiatan ataupun program yang dirancang. Apabila telah sampai terhadap sesuatu yang ditetapkan atau sesuatu yang menjadi tujuannya maka hal itu dapat dikatakan efektif dalam arti lain efektivitas adalah sebutan untuk sesuatu yang berhasil dalam pekerjaannya entah itu dengan menggunakan strategi ataupun merancang banyak perencanaan namun sesuatu yang berhasil atau menjadi efektif berawal dari strategi dan perencanaan yang digunakan dengan melakukan beberapa program dan kegiatan1

Jadi, dari penjelasan di atas dapat disimpulkan bahwasanya efektivitas adalah hasil dari beberapa perencanaan dengan melakukan beberapa strategi untuk mencapai tujuan dan sasarannya. Efektivitas juga bentuk dari penilaian kinerja seseorang, jika perencanaan tersebut tidak menjadikan kinerja semakin baik

\footnotetext{
${ }^{1}$ Rosalina Iga "Efektivitas Program Nasional Pemberdayaan Masyarakat Mandiri Perkotaan Pada Kelompok Pinjaman Bergulir Didesa Mantren"Jurnal EPM: Februari 2012) Vol 1. No 1
} 
maka sudah jelas adanya kekurangan dalam rancangan perencanaan yang sudah dibuat. Menurut Richard M. Steers ukuran dari efektivitas dapat dilihat dari 6 sudut;

- Proses

Proses merupakan sesuatu yang dapat menentukan hasil dalam mencapai tujuannya, untuk itu dalam proses adanya segala unsur keseluruhan untuk dijadikan sebagai upaya pencapaian tujuan yang harus menjadi fokus dalam menentukan tujuan. Oleh sebab itu, agar supaya hasil akhir dapat memuaskan maka perlu untuk menjamin tujuan pencapaiannya dengan menetapkan kurun waktu yang dibutuhkan untuk segera diselesaikan. Setelah itu juga menetapkan sasaran yang akan dicapai setiap waktunya untuk mendapatkan target yang kongkrit dalam mencapai tujuannya. Sasaran merupakan indikator kunci untuk sampai terhadap tujuan tujuan akhir semakin terjamin, diperlukan pentahapan, baik dalam arti pentahapan pencapaian bagian-bagiannya maupun pentahapan dalam arti periodisasinya. Pencapaian tujuan terdiri dari beberapa aktor, yaitu: Kurun waktu dan sasaran yang merupakan target kongktit .

- Pengukuran

Pengukuran atau integrasi yaitu mengukur terhadap sejauh mana kemampuan kinerja dalam suatu organisasi dalam berinteraksi sosial, mengembangkan konsensus dan kemampuan berkomunikasi dengan anggota lainnya. Pengukuran ini lebih memfokuskan terhadap sosialisasi nya.

- Beradaptasi

Kemampuan beradaptasi juga menjadi peran penting bagi tenaga kerja untuk menciptakan hubungan kerja sama yang baik dan mampu beradaptasi dengan lingkungannya. Adaptasi adalah kemampuan organisasi untuk menyesuaikan diri dengan lingkungannya. 2

Sistem informasi manajemen atau yang sering dikenal dengan SIM merupakan sistem perencanaan bagian dari pengendalian

${ }^{2}$ Richard M Steers "Efektivitas Organisasi" (Yogyakarta; Pustaka Pelajar 1999) h.53 
internal dalam bisnis yang terdiri atas pemanfaatan dokumen, manusia, teknologi, serta prosedur dalam akuntansi manajemen. Tujuan dari SIM adalah untuk memecahkan beragam masalah yang meliputi layanan, biaya, srta strategi. hal ini sejalan dengan pendapat yang dikemukakan oleh O'Brien yang mengatakan jika,

Sistem informasi manajemen merupakan kombinasi dari seluruh elemen baik dari segi sumber daya manusianya, berupa software ataupun hardware yang dijadikan sebagai jaringan dalam berkomunikasi dan untuk mengumpulkan sejumlah data yang berguna untuk mengubah dan menginformasikan terhadap organisasi.

Pendapat ini pun selaras dengan pendapat yang dikemukakan oleh Laudon jika, Sistem informasi merupakan rangkaian dari sejumlah komponen yang saling terkait antara satu dengan yang lain untuk mengumpulkan, mengelola, mengarsipkan dan mendistribusikan informasi yang bertujuan untuk mendukung saat pengambilan keputusan, mengontrol, sekaligus berkoordinasi didalam organisasi. Berbeda dengan pendapat Bodnar dan Hopwood yang mengatakan jika SIM adalah kumpulan perangkat keras dan perangkat lunak yang dirancang untuk menstransformasikan data dalam bentuk informasi yang berguna.3

Pendapat yang dikemukakan oleh O'Brien dan Laudon sangatlah relevan dengan aktivitas manajemen sistem informasi dikarenakan fungsi dari sistem ini tidak terbatas pada pihak manajemen saja akan tetapi juga pada bagi organisasi secara keseluruhan. Salah satu manfaat dari SIM yaitu meningkatkan kualitas dari SDM dikarenakan unit sistem kerja akan lebih terkoordinasi serta sistematis serta mempermudah pihak manajemen dalam melakukan pengawasan, perencanaan,

\footnotetext{
${ }^{3}$ Anastasia Lipursari PERAN SISTEM INFORMASI MANAJEMEN (SIM) DALAM PENGAMBILAN KEPUTUSAN (Jurnal STIE Semarang) VOL5,NO1,Edisi Februari 2013 (ISSN:2252-7826)
} 
pengarahan serta pendelegasiankinerja pada semua departemen yang mempunyai koordinasi dan hubungan. 4

Jadi, yang dimaksud dengan Sistem Informasi Manajemen merupakan serangkaian komponen yang memanfaatkan sejumlah teknologi atau media dan sumberdaya manusia. Dalam kata lain memadukan beberapa unsur tersebut didalam suatu aktivitas manajemen. Sistem informasi sendiri sudah memiliki rangkaian proses sedangkan manajemen adalah rangkaian yang mengolah data-data dalam sistem informasi.

Kinerja pegawai didalam suatu organisasi dapat dipengaruhi oleh beberapa banyak faktor yang meliputi antara; faktor dari lingkungan kerja, faktor gaji, faktor dari segi motivasi, budaya dalam organisasi, faktor dari kepemimpinan, disiplin dan yang terakhir faktor dari sistem informasi manajemen. Faktor tersebut dapat meningkatkan kinerja para pegawai ataupun sebaliknya tergantung dari sejauh mana suatu organisasi dapat mengimplementasikan faktor-faktor pendukung dalam meningkatkan kinerja karyawannya. Salah satunya adalah sistem informasi manajemen yang dapat mendukung dalam meningkatkan kualitas kinerja para pegawai apalagi dengan didukung dengan faktor gaji. Suatu organisasi dapat dikatakan sangat efektif jika organisasi tersebut mampu memberikan kepuasan terhadap stakeholder pendidikan.

Menurut pendapat beberapa ahli mengenai pengertian kinerja sebagaimana yang disebutkan oleh Wirawan, kinerja adalah keluaran yang dihasilkan oleh fungsi-fungsi atau indikatorindikator suatu pekerjaan atau suatu profesi dalam waktu tertentu.

Sedangkan menurut Mangkunegara mendefenisikan kinerja merupakan sesuatu yang dicapai seseorang dengan kualitas dan kuantitas kerja yang dihasilkan sesuai dengan tanggung jawabnya masing-masing. Sejalan dengan beberapa pendapat di atas Hariman dan Hilgert, mengemukakan kinerja sebagai suatu perwujudan kerja aparatur yang selanjutnya akan dijadikan dasar penilaian atas

${ }^{4}$ Sugi Priharto, diakses pada tanggal 19 Oktober 2020, pukul 07. 52, https://acurate.id/marketing-manajemen/sistem-informasi-manajemenarti-fungsi-contoh-dan-manfaatnya/ 
tercapai atau tidaknya target dan tujuan suatu organisasi pemerintahan, kinerja meliputi hasil-hasil yang telah dicapai oleh karyawan dalam melaksanakan tugas yang diberikan.

Jadi,yang dimaksud dengan kinerja menurut pemaparan diatas kinerja dapat diartikan sebagai memberikan sesuatu yang dapat menghasilkan sesuatu sehingga hal tersebut disebut sebagai pekerjaan yang memiliki waktu tertentu.

Sebagaimana yang sudah dijelaskan di atas bahwasanya faktor yang mempengaruhi kinerja salah satunya adalah sistem informasi manajemen (SIM). Pengelolaan SIM akan berpengaruh terhadap kinerja suatu organisasi, pengelolaan sistem informasi manajemen yang baik akan mampu mempengaruhi pada aktivitas kerja karyawan. Menurut Pendapat Loudon menyebutkan bahwasanya SIM akan dapat disebut beroperasi secara baik apabila penggunaannya mudah untuk diakses, sehingga intensitas penggunannya tinggi dan pada akhirnya akan menimbulkan kepuasan pengguna terhadap SIM. Jika SIM tersebut memiliki kualitas sesuai dengan yang diharapkan dan dapat mendukung keberadaan pekerjaan yang karyawan lakukan, maka kinerja individu tersebut tentu akan tercapai, begitu juga sebaliknya5

Kementrian agama yang melalui Direktorat Pendidikan Agama Islam telah menetapkan peluncuran aplikasi yang disebut Siaga pada tahun 2019 sebagai apresiasi yang dibuat oleh kementerian agama untuk guru PAI yang berada dalam naungan sekolah umum yang tidak memiliki kejelasan manajemen dalam pelaksanaan sertifikasi yang disebabkan oleh adanya dua birokrasi antara Departemen Agama dengan Departemen Pendidikan Nasional memonitoring artinya guru PAI tidak memiliki suatu lembaga yang jelas, yang dapat menaungi dalam kinerjanya, untuk itu aplikasi Siaga hadir untuk menjawab problematika tersebut meskipun para guru mendapatkan gaji dari Dinas Pendidikan Kota/Kabupaten lain halnya dengan Guru PAI yang mana dalam pelaksanaan sertifikasi

\footnotetext{
${ }^{5}$ Ahmad Rizal "Analisis Kualitas Sistem Informasi Manajemen Terhadap Kinerja"Jurnal Manajemen Bisnis (JMB: Juni 2019) Vol. 31. No 1. Manajemen Bisnis (JMB), Volume 31 No 1 ISSN 2622-8351
} 
justru dibawah wewenang Departemen Agama oleh sebab itulah Kementerian Agama Republik Indonesia melewati Dirjen Pendis Direktorat PAI meluncurkan aplikasi yang diberi nama SIAGA yaitu Sistem Informasi dan Administrasi Guru Agama.

Aplikasi Sistem Infromasi dan Administrasi Guru Agama (SIAGA) merupakan sistem data online khusus untuk guru agama. Aplikasi Siaga ini berintegrasi dengan Emis (Education Manajemen Information System) yang menampung semua kebutuhan administrasi guru agama seperti berkas sertifikasi dan verval NRG, TPG dan lain-lain. Dengan adanya Siaga ini kementerian agama bisa memantau perkembangan peningkatan mutu guru agama misalnya guru memiliki pengetahuan terhadap manajemen dan proses terhadap pembelajaran yang maksimal serta menguasai teknologi.6

Pada artikel ini penulis membatasi masalah yang akan diteliti yaitu efektivitas aplikasi Siaga dalam kemudahan guru dalam mengakses data-data, mempercepat pencairan tunjangan guru, dan kemudahan evaluasi kinerja guru yang ada di Kemenag Kabupaten Bangkalan.

\section{Metodologi}

Penelitian ini dilakukan dengan menggunakan metode kualitatif dengan pendekatan deskriptif yang cenderung terhadap analisis data. Subjek dalam penelitian ini adalah guru PAIS Kabupaten Bangkalan, sedangkan objek dalam penelitian ini adalah SIM Siaga yang ada di Kemenag Kabupaten Bangkalan. Teknik pengumpulan data dilakukan dengan observasi lapangan dan wawancara yang dilakukan pada tanggal tugas yang telah ditetapkan oleh kampus terkait. Teknik analisis data dilakukan dengan tahapan-tahapan sebagai berikut:

- Menyiapkan beberapa bahan pertanyaan

\footnotetext{
${ }^{6}$ Ifrod Maksum, diakses pada tanggal 19 Oktober 2020, pukul 07.30, https://www.nomiford.com/2019/02/panduan-aplikasi-siaga-sisteminformasi.html
} 
- Melakukan pengembangan wawancara kepada narasumber yang berkaitan dengan SIM Siaga dengan mengacu pada pedoman wawancara

- Menganalisis semua data yang dikumpulkan. Setelah semua data diperoleh dari wawancara, pengamatan yang sudah dituliskan dalam catatan dokumen resmi/pribadi, recorder, foto hasil dikumpulkan kemudian dibaca, dipelajari, dipahami, dan ditelaah.

- Menyimpulkan hasil penelitian dalam bentuk deskripsi kualitatif.

\section{Hasil dan Pembahasan}

Berdasarkan Buku Penyusunan Dan Pengumpulan Data Statistik Kabupaten Bangkalan yang dibuat oleh Dinas Komunikasi Dan Informatika Kabupaten Bangkalan Menyebutkan Bahwasanya Kabupaten Bangkalan merupakan bagian dari salah satu kabupaten yang ada di Provinsi Jawa Timur. Letak Kabupaten Bangkalan berada tepat di bagian barat dari Pulau Madura. Tepatnya dari letak koordinat maka Kabupaten Bangkalan berada diantara koordinat 112o40'06" - 113o. 08'04" Bujur Timur juga 6o51'39"- 7o11'39" Lintang Selatan, dengan luas wilayah 1.260,41 km2 .

Letak geografis tersebut mendukung Kabupaten Bangkalan menjadi wilayah yang strategis posisi wilayah Kabupaten Bangkalan yang berada paling ujung barat dari pulau Madura menjadikan Kabupaten Bangkalan sebagai pintu gerbang utama pulau Madura. Kabupaten Bangkalan berbatasan langsung dengan beberapa wilayah ataupun tempat di Provinsi Jawa, adapun batas wilayah Kabupaten Bangkalan sebagai berikut : - Bagian Utara berbatasan langsung dengan Laut Jawa, - Bagian Timur wilayah berbatasan dengan wilayah Kabupaten Sampang, - Bagian Selatan wilayah berbatasan dengan selat Madura, - Barat wilayah berbatasan dengan selat Madura.7

\section{Profil Kantor Kemenag Bangkalan}

Nama instansi : Kementerian Agama Kabupaten Bangkalan

${ }^{7}$ Dinas Komunikasi Dan Informatika Kabupaten Bangkalan "Penyusunan Dan Pengumpulan Data Statistik Daerah Kabupaten Bangkalan 2018" 
Alamat : Jl. Soekarno Hatta No.94 Bangkalan

Status lembaga : Negeri

Visi

“Terwujudnya masyarakat Kabupaten Bangkalan yang taat beragama, rukun cerdas, dan sejahtera lahir batin dalam rangka mewujudkan Indonesia yang berdaulat, mandiri dan berkepribadian berlandaskan gotong royong"

Misi

- Meningkatkan pemahaman dan pengalaman ajaran agama

- Memantapkan kerukunan intra dan antar umat beragama

- Menyediakan pelayanan kehidupan beragama yang merata dan berkualitas

- Meningkatkan pemanfaatan dan kualitas pengelolaan potensi ekonomi keagamaan

- Mewujudkan penyelenggaraan ibadah haji dan umrah yang berkualitas dan akuntabel

- Meningkatkan akses dan kualitas pendidikan umum berciri agama, pendidikan agama pada satuan pendidikan umum, dan pendidikan keagamaan

- Mewujudkan tata kelola pemerintahan yang bersih, akuntabel, dan terpercaya

Berdasarkan Keputusan Menteri Agama RI Nomor 373 Tahun 2002 tentang Organisasi dan Tata Kerja Kantor Wilayah Kementerian Agama Provinsi dan Kantor Kementerian Agama Kabupaten/Kota (disempurnakan) sebagai berikut:

- Kedudukan Kantor Wilayah Kementerian Kabupaten/Kota adalah instansi vertical Kementerian Agama yang berada di bawah dan bertanggung jawab langsung kepada Kepala Kantor Wilayah Kementerian Agama provinsi. Alamat Kantor Kementerian Agama Kabupaten Bangkalan adalah di Jalan Soekarno Hatta No. 9ATelp./Fax. (031) 3095039 Bangkalan.

- Tugas Pokok Kementerian Agama Kabupaten Bangkalan mempunyai tugas melaksanakan tugas pokok dan fungsi Kementerian Agama dalam wilayah kabupaten/kota berdasarkan kebijakan Kepala Kantor Wilayah Kementerian 
Agama Provinsi dan Peraturan Perundang-undangan yang berlaku.

- Fungsi dalam melaksanakan tugas sebagaimana dimaksud di atas, Kantor Kementerian Agama Kabupaten Bangkalan menyelenggarakan fungsi :

- Perumusan dan penetapan visi, misi dan kebijakan teknis dibidang pelayanan dan bimbingan kehidupan beragama kepada masyarakat di kabupaten Bangkalan.

- Pelayanan, bimbingan dan pembinaan di bidang haji dan umroh.

- Pelayanan, bimbingan dan pembinaan di bidang pendidikan madrasah, pendidikan agama dan keagamaan.

- Pembinaan kerukunan umat beragama.

- Pelaksanaan kebijakan teknis di bidang pengelolaan administrasi dan informasi.

- Pengorganisasian perencanaan, pengendalian, pengawasan dan evaluasi program.

- Pelaksanaan hubungan dengan pemerintah daerah, instansi terkait dan lembaga masyarakat dalam rangka pelaksanaan tugas Kementerian di Kabupaten Bangkalan.8

\section{Kantor PAIS di Kementerian Kabupaten Bangkalan}

Sebelum membahas Sistem Informasi Manajemen di Kantor Pendidikan Agama Islam (PAIS) peneliti akan memaparkan fungsi dan susunan organisasi di bidang Pendidikan Agama Islam menurut Kementerian Agama Jawa Timur.

Fungsi dan Peran Seksi PAIS (Pendidikan Agama Islam) meliputi;

- Menyiapkan perumusan mengenai kebijakan teknis dan perencanaan diseksi pendidikan agama islam

- Memberikan pelayanan, melaksanakan bimbingan dan pembinaan dibilang pendidikan agama islam dari jenjang pendidikan PAUD, TK, SD/SDLB, SMP/SMPLB, SMA/SMALB/SMK sekaligus melakukan pengelolaan sistem informasi pendidikan agama islam

${ }^{8}$ Wawancara Dengan Syamsul Mu'arif (Tenaga Usaha Kantor Kementerian Agama Kabupaten Bangkalan) Pada Tanggal 30 Agustus 2020 
- Mengevaluasi dan melakukan penyusunan laporan di bidang pendidikan agama islam.

Susunan organisasi seksi pendidikan agama islam meliputi;

- Seksi pendidikan agama islam pada PAUD dan TK tugas: melakukan penyiapan bahan pelaksanaan pelayanan,bimbingan teknis,dan pembinaan dibidang pendidikan agama islam pada PAUD dan TK

- Seksi pendidikan agama islam pada SD/SDLB tugas: melakukan penyiapan bahan pelaksanaan pelayanan, bimbingan teknis, dan pembinaan dibidang pendidikan agama islam pada SD/SDLB

- Seksi pendidikan agama islam pada SMP/SMPLB tugas: melakukan penyiapan bahan pelaksanaan pelayanan, bimbingan teknis,dan pembinaan dibidang pendidikan agama islam pada SMP/SMPLB

- Seksi pendidikan agama islam pada SMA/SMALB/SMK tugas: melakukan penyiapan bahan pelaksanaan pelayanan, bimbingan teknis, dan pembinaan dibidang pendidikan agama islam pada SMA/SMALB/SMK

- Seksi sistem informasi pendidikan agama islam tugas: melakukan penyiapan bahan pelaksanaan pelayanan, bimbingan teknis dan pembinaan dibidang sistem informasi pendidikan agama islam 9

\section{SIM SIAGA DI Kantor PAIS}

Sistem informasi manajemen merupakan penerapan sistem informasi di dalam suatu organisasi yang bertujuan untuk mendukung informasi-informasi yang dibutuhkan oleh semua tingkatan manajemen. Selain itu, Sistem Informasi Manajemen yaitu suatu efektifitas dalam mengelola data agar menjadi sangat mudah untuk diterapkan dalam suatu administrasi khususnya administrasi pendidikan. Akan sangat menjadi efektif apabila system informasi manajemen yang digunakan sudah berbasis teknologi sehingga dalam menginput data tidak membutuhkan waktu yang cukup

${ }^{9}$ Kementrian Agama Jawa Timur Diakses Pada Tanggal 20 Oktober Pukul 07: 43 https://jatim.kemenag.go.id/artikel/17594/bidang- pendidikanagama-islam-pais 
lama dan dapat diakses dimanapun dan kapanpun saja. Seperti halnya aplikasi Siaga, yang dapat digunakan oleh semua guru-guru sekolah, pengawas pendidikan dan Kepala Sekolah.

Jadi, Sistem Informasi Manajemen di Kantor PAIS Kabupaten Bangkalan dengan memanfaatkan teknologi yang disebut sebagai aplikasi Siaga sebagaimana yang sudah diluncurkan oleh Kementerian Agama yang melewati Dirjen Pendis Direktorat PAI untuk operator aplikasi tersebut menjadi tugas dari bidang Pais. Dalam memberikan pelayanan, bimbingan dan pembinaan terhadap Guru-guru PAI.

Aplikasi Siaga adalah Sistem Informasi dan Administrasi Guru Agama. yang dikembangkan pada tahun 2019 oleh Direktorat Pendidikan Agama Islam yang berfungsi untuk memverikasi, Validasi data Guru dan Pengawas Pendidikan Agama Islam. Aplikasi Siaga ini merupakan alat yang digunakan untuk memonitoring beberapa program Direktorat Pendidikan Agama Islam. untuk itu bagi Guru-Guru PAI diwajibkan dalam menggunakan aplikasi tersebut.

SIM SIAGA adalah sistem informasi yang berbentuk alamat web yang telah digunakan oleh Seksi PAIS, aplikasi yang dapat mengelola sejumlah data yang berskala besar yang mana dari data itulah dapat terdeteksi untuk dibaca dan dapat diproses sesuai dengan kebutuhan nya. Selain itu sebagai acuan dalam mengambil keputusan baik berupa bimbingan teknis ataupun pembinaan dan lain sebagainya. Lembaga Kementerian Agama Kabupaten khsusunya Seksi dalam Pendidikan Agama Islam juga berperan memberikan pelayanan terhadap Guru-guru PAI pada tingkat SD, SMP, SMA/SMK di Kabupaten Bangkalan.

Aplikasi Siaga memiliki beberapa pintu akun seperti akun provinsi, kabupaten, madrasah dan guru yang dapat mengolah berbagai kebutuhan administrasi seperti pada Simpatika. Adapun menu pada Siaga yaitu pada verval yang terdiri dari verval biodata, verval jadwal mengajar, dan tugas tambahan, verval sertifikasi, dan verval NRG. Sertifikasi terdiri dari kelayakan TPG, dispensasi, SK pencairan, pencairan TPG. Pendidik terdiri atas data portofolio, personal, status pegawai, pendidikan, keluarga, riwayat pelatihan, 
prestasi. Sekolah terdiri dari sekolah induk, sekolah non induk, jadwal dan tugas. Terakhr adalah data administrasi sertifikasi, NRG, TPG, SKMT, dan mutasi.10

Menurut Harsono Arief yang bertugas sebagai operator Aplikasi Siaga di Kantor PAIS Kemenag Bangkalan mengakui, jika aplikasi tersebut sangat efektif untuk digunakan dibandingkan aplikasi EMIS dimana beberapa fitur-fitur yang sangat mendukung didalamnya, dan sama sekali tidak menemukan kendala apapun. meskipun ada sebagian fitur yang masih tidak dapat berjalan secara efektif dikarenakan aplikasi tersebut masih terbilang sangat baru yang membutuhkan inovasi-inovasi dalam pengembangannya. Siaga dirasa dapat memudahkan tugas-tugas seksi PAIS dalam memonitoring data dalam aplikasi Siaga didalamnya memuat tentang PTK, Verval, Sertifikasi, Laporan TPG, dan Kekurangan anggaran yang dalam pengelolaannya dirasa lebih efektif dan lebih mudah dalam mengaplikasikannya baik oleh pihak PAIS, GuruGuru PAI dan juga Pengawas PAI.11

Kelebihan lainnya yang ditawarkan siaga adalah terbukti bahwa aplikasi yang satu ini dapat mempercepat pencairan tunjangan guru. Harsono Arief juga menegaskan bahwa dengan adanya siaga ini pencairan tunjangan guru lebih efektif, karena koordinasi yang dilakukan juga lebih cepat dan guru-guru juga respontif dalam menyikapi perintah dari atasan. Sehingga data-data yang diperlukan atau dibutuhkan dalam pencairan tunjangan guru lebih cepat selesai dan pencairan tunjangan guru lebih cepat selesai pula.

Adapun hal lain dalam siaga adalah kemudahan dalam evaluasi kinerja guru. Evaluasi guru juga dapat dilakukan dalam siaga salah satunya dengan menilai kelengkapan administrasi guru seperti jadwal mengajar, absensi dan lain sebagainya. Sekalipun ada yang kurang sesuai dengan Kriteria yang diminta dalam aplikasi namun adanya koordniasi yang kuat serta guru yang respontif ini

\footnotetext{
${ }^{10}$ Ifrod Maksum, diakses pada tanggal 19 Oktober 2020, pukul 07.30, https://www.nomiford.com/2019/02/panduan-aplikasi-siaga-sisteminformasi.html

${ }^{11}$ wawancara dengan Harsono Arief (Operator Aplikasi Siaga) pada tanggal 15 Oktober 2020
} 
memudahkan semua pihak yang terkait dengan mudah menyelsaikan tugas masing-masing sehingga Harsono Arif mengatakan bahwa selama ia menjadi operator Siaga di kemenag kabupaten Bangkalan tidak ada kendala dan aplikasi siaga ini adalah aplikasi yang efektif dan cocok di seksi PAIS mengingat bagaimana kemudahannya selama ini.

Dalam pengaplikasiannya, manfaat siaga selama ini sangat membantu dalam memudahkan guru dalam mengakses data-data, mempercepat pencairan tunjangan guru, dan kemudahan evaluasi kinerja guru yang ada di Kemenag Kab. Bangkalan dengan kata lain siaga dirasa sangat efektif dibanding aplikasi yang sebelumnya.

Jadi, Berdasarkan dari teori yang sudah dijelaskan, Aplikasi Siaga mampu menjadikan kinerja Guru PAI menjadi efektif dengan diberikan tunjangan guru sebagai motivasi dalam setiap kinerjanya.

\section{Kesimpulan}

Sistem informasi manajemen telah mengalami banyak perkembangan dalam menunjang aktivitas dan efektivitas suatu kinerja pegawai khususnya Pegawai Pais yang bertugas memonitoring Guru PAI dan Pengawas PAI yang berada dalam dua lembaga. Untuk pelaksanaan monitoring berada dibawah kendali Kemenag Bangkalan sedangkan dalam aktifitas pendidikan nya masih tetap berada dalam wewenang Dinas Pendidikan sehingga Aplikasi SIM Siaga diluncurkan sebagai apresiasi terhadap kinerja Guru pendidikan Agama Islam yang mana aplikasi tersebut sangatlah efektif untuk digunakan.

Kantor PAIS di Kemenag Kabupaten Bangkalan, yang mana kantor tersebut berlokasi di ibu kota Madura dalam Sistem Informasi Manajemen nya-pun juga dikelola dengan sangat baik untuk memberikan pelayanan, bimbingan dan pembinaan terhadap Guru-guru PAI sebangkalan dengan pelantara Aplikasi Siaga yang secara teknis SIM yang sudah memuat segala aspek manajemen. Meskipun berlokasi di Madura yang lebih kental sebagai penduduk desa Aplikasi Siaga yang berbentuk alamat web yang mungkin bagi sebagian Guru PAI mengalami kesulitan, Kantor Pais juga 
memberikan Ruang bagi Guru-guru PAI untuk mendapatkan bimbingan mengenai teknis penggunaan aplikasi siaga.

Untuk itu, Kantor PAIS selain menjadi pusat manajemen Pendidikan Agama Islam bidang tersebut juga berfungsi sebagai Hubungan Masyarakat yang dikhususkan untuk Guru-guru PAI dalam memberikan pelayanan.

Dalam Karya tulis ini, Peneliti menyadari adanya kekurangankekurangan yang perlu diperbaiki. Untuk itu peneliti mengharapkan masukan dan saran bapak atau ibu untuk dijadikan sebagai bahan evaluasi guna memperbaiki karya tulis ini.

\section{References}

Ahmad, Rizal "Analisis Kualitas Sistem Informasi Manajemen Terhadap Kinerja" Jurnal Manajemen Bisnis (JMB: Juni 2019) Vol.31. No1. Manajemen Bisnis (JMB), Volume 31 No.1 ISSN 2622- 8351.

Dinas Komunikasi Dan Informatika Kabupaten Bangkalan "Penyusunan Dan Pengumpulan Data Statistik Daerah Kabupaten Bangkalan 2018"

Kementrian Agama Jawa Timur Diakses Pada Tanggal 20 Oktober Pukul 07:

https://jatim.kemenag.go.id/artikel/17594/bidangpendidikan-agama-islam-pais

Lipursari, Anastasia. 2013.Peran Sistem Informasi Manajemen (Sim) Dalam Pengambilan Keputusan (Jurnal STIE Semarang) Vol5, No 1, Edisi Februari (ISSN:2252-7826).

Maksum, Ifrod. diakses pada tanggal 19 Oktober 2020, pukul 07.30, https://www.nomiford.com/2019/02/panduan-aplikasi-siagasistem-informasi.html

Priharto, Sugi. diakses pada tanggal 19 Oktober 2020, pukul 07. 52, https://acurate.id/marketing-manajemen/sistem-informasimanajemen-arti-fungsi-contoh-dan-manfaatnya/ 
Holifah Kurniyah, Imam Tirmidzi A, Nur Hasanah

Richard M Steers "Efektivitas Organisasi" (Yogyakarta; Pustaka Pelajar 1999) h.53

Wawancara dengan Harsono Arief (Operator Aplikasi Siaga) pada tanggal 15 Oktober 2020

Wawancara Dengan Syamsul Mu'arif (Tenaga Usaha Kantor Kementerian Agama Kabupaten Bangkalan) Pada Tanggal 30 Agustus 2020 